\title{
HUMAN HERPESVIRUS 6 PRIMARY INFECTION - IS THAT SIMPLE?
}

K. Divakova ${ }^{1}$, E. Kishkurno ${ }^{2}$, O. Romanova ${ }^{1}$

${ }^{1}$ Belarusian State Medical University, Pediatric Infectious Diseases Department ${ }^{2}$ Belarusian Medical Academy of Post-Graduate Education, Infectious Diseases Department

\section{GASE PRESENTATION SUMMARY}

- A 7-month-old male presented with an arrest of ongoing activity with altered awareness, a blank empty stare and eye deviation.

- The child's temperature was normal, his physical exam was unremarkable.

- CSF examination revealed 1 WBC/mmc, glucose $62 \mathrm{mg} / \mathrm{dl}$ and protein $58 \mathrm{mg} / \mathrm{dl}$.

- The patient was started on empiric acyclovir, as acute encephalitis was suspected.

- Next day febrile fever, repetitive myoclonic seizures and maculopapular rash on his face and trunk appeared.

- In few days left-sided hemiparesis developed.

- MRI on the 7th day of the disease was normal.

- Ceftriaxone and antiepileptic therapy was prescribed.
- All results, including immunological and virological tests by PCR in blood and CSF, were negative.

- In CSF on the $8^{\text {th }}$ day of disease HHV-6 DNA by qualitative PCR was negative whereas the blood sample examined for PCR HHV-6 was positive.

- The EEG on the $13^{\text {th }}$ day of the disease revealed interhemispheric asymmetry.

- The patient received immunoglobulin $(2 \mathrm{~g} / \mathrm{kg})$ and intravenous ganciclovir (5mg/kg twice daily for 14 days), resulting in a slight improvement of the clinical condition.

- Nevertheless, 7 months later, he still had left-sided hemiparesis and partial seizures.

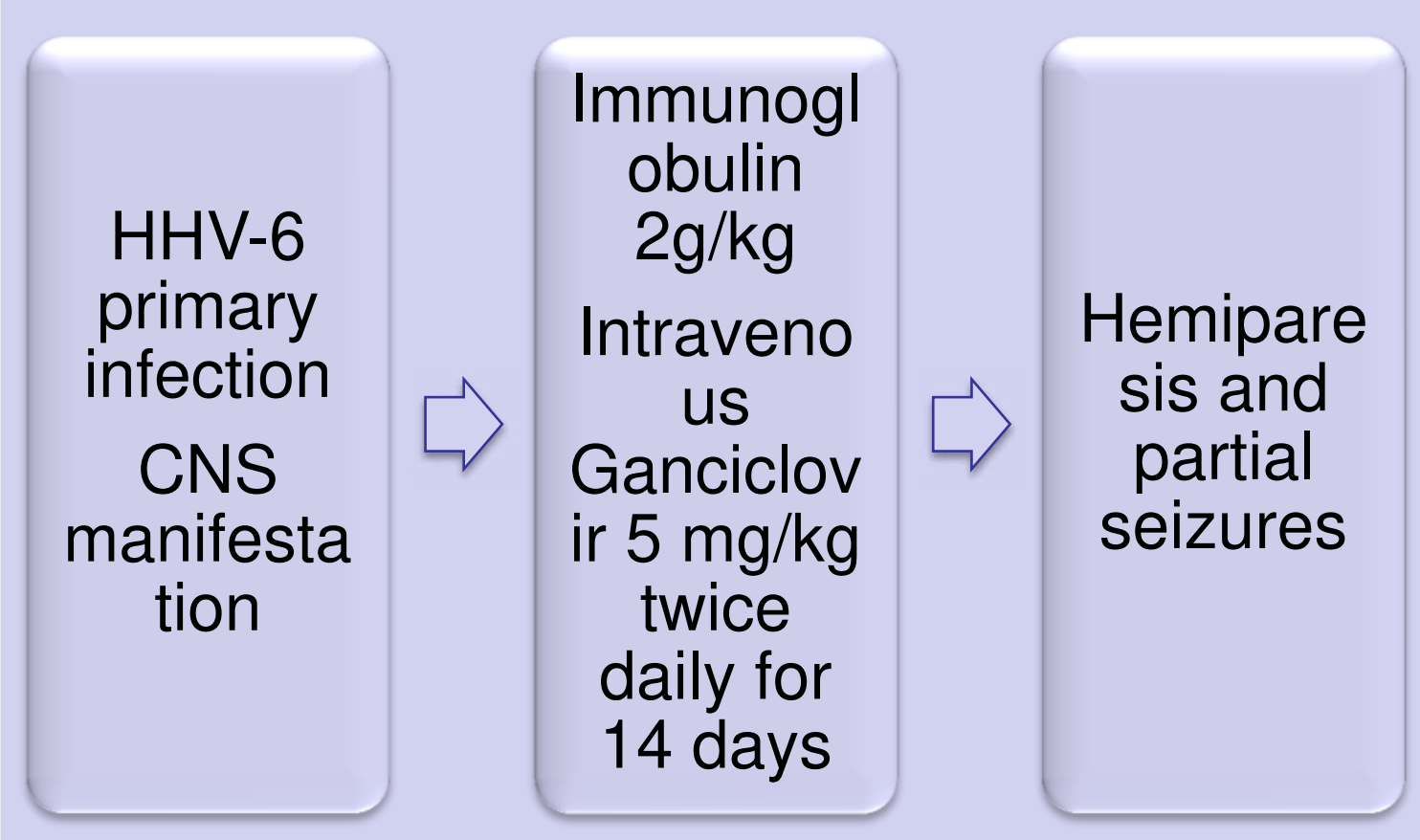

\section{DISEUSSION}

\section{BONIIAT}

\section{REFERENGES}

Comparison of the levels of human herpesvirus 6 (HHV-6) DNA and cytokines in the cerebrospinal fluid 6 (HHV-6) DNA and cytokines in the cerebrospinal thu and serum of children with HHV-6 encephalopathy. Kawabe S, et al. 8, 2010, Journal of Medical Virology, ol. 82, pp. 1410-1415.

2. Roseolovirus-associated encephalitis in immunocompetent and immunocompromised individuals. Ongradi J., Ablashi D., Yoshikava T., Sterez B., Ogata M. 1, 2017, Journal of Neurology, Vol. 23, pp. 1-19. 